\title{
Linguistic and Religious Continuity and Change among the Lelna of Northwestern Nigeria
}

\author{
Theodore Randall \\ Department of Sociology and Anthropology, Indiana University South Bend, USA
}

\begin{abstract}
The factors shaping the contemporary linguistic and religious expression of the Lelna of Nigeria are discussed. Qualitative research reveals the increasing influence of the Hausa language, the increasing population of the Lelna ethnic group, the current establishment and function of the national administrative/state boundaries of Nigeria, and the promotion of multiculturalism and multilingualism on contemporary Lelna linguistic expression. Extensive Islamic contact via the Hausa since the early nineteenth century and Christian missionizing efforts since the early twentieth century constitute the major factors shaping contemporary Lelna religious expression. Specific processes the Lelna implement to retain their language and indigenous religious beliefs and practices include the frequent utilization of the Germache spirit shrine and local development of Lelna literature. Contemporary Lelna linguistic and religious expression must be understood in the greater context of ethnic identity development, linguistic hegemony, and religious pluralism in Africa.
\end{abstract}

\section{Keywords}

Lelna, Nigeria, Multilingualism, Linguistic hegemony, Religious pluralism, Ethnic identity

\section{Introduction}

Africa constitutes one of the most linguistically and religiously diverse regions of the planet. Of the 7,099 living languages present on the planet, 2,144 are located in Africa [1]. Moreover, no one single religion characterizes the entire continent. Africans tend belong to one of three major religious designations. At present $49 \%$ of Africans are Christian, $42 \%$ Muslim, and 9\% adhere to African Traditional Religion (also called animistic or indigenous religions) [2] ${ }^{\text {a }}$. The latter religious designation refers to a multitude of often ethnic group specific religious (ethnoreligious) beliefs and practices that existed in Africa long before the introduction of Christianity and Islam [3]. The particular religious expressions of each of

aThis author acknowledges the problematic nature of the use of "traditional" when referring to the African religious beliefs and practices existed prior to the presence and wide acceptance of Christianity and Islam. According to Martin and O'Meara [38], referring to aspects of African culture as "traditional" as juxtaposed to modern is misleading because "traditional" cultural characteristics continue to exist in modern Africa. In this sense, it would seem that the use of the term "indigenous" would seem more appropriate. However, in conformity to the designation used by African authors such as Mbiti [45] and Idowu [46], this paper will utilize the term, "traditional" African religion to refer to those religious beliefs and practices indigenously developed by Africans that existed in Africa prior to Christian and Islamic contact. This designation is also used by more contemporary African authors [4,47]. This author will proceed with this paper in conformity with these authors for the sake of uniformity. these can be highly distinct from others or resemble other African Traditional Religions [4]. In addition, a single ethnic group can exclusively adhere to a specific religion or adhere to variety of religious designations. Whatever the case, African ethnic groups do not exist in isolation.

African ethnic groups interact with other ethnic groups (both large and small) and are exposed to global and historical processes such as colonialism and globalization in a variety of contexts, sometimes adopting new cultural characteristics from these groups while at other times intentionally striving to maintain their own distinct cultural characteristics. The particular manner in which cultural change does or does not occur is dependent on a variety of factors and these factors occur in a variety of combinations. One of the most apparent factors involves the interaction of an ethnic population with a small less powerful population with an ethnic group with a large more powerful population. Given the tremendous degree of ethnic

*Corresponding author: Theodore Randall, PhD MPH, Associate Professor, Department of Sociology and Anthropology, Indiana University South Bend, South Bend, Indiana 46545, USA

Accepted: January 13, 2020

Published online: January 15, 2020

Citation: Randall T (2020) Linguistic and Religious Continuity and Change among the Lelna of Northwestern Nigeria. Insights Anthropol 4(1):224-232 
diversity in Africa, such interethnic interaction between small less powerful ethnic groups and large more powerful ethnic groups occurs quite frequently. With this said, there is perhaps no other country in Africa where such interethnic interaction is more apparent than Nigeria, the continent's most populous and ethnically diverse country. This paper examines how one of Nigeria's ethnic groups, the Lelna maintain their linguistic and religious distinctiveness amidst their interaction with their larger neighbor, the Hausa in a country that is attempting to preserve its national identity by accommodating its largest ethnic groups and attempting to diminish interethnic conflict ${ }^{b}$.

\section{The National Context: The Language and Religious Composition of Nigeria}

Nigeria is a highly linguistic and religious diverse country. According to Ethnologue [1], 526 of the 2144 (nearly one quarter) of all of Africa's languages are found in Nigeria. This linguistic diversity manifests itself throughout the country in a regional configuration. Nigeria's three largest languages Hausa, Ibo, and Yoruba dominate the north, southeast, and southwest regions of the country respectively. The Hausa (and related peoples) people constitute 29\% (53 million) on Nigeria's population, while the constitute Yoruba $21 \%$ (38 million) and Ibo constitute 18\% (33 million) of the Nigerian population. Furthermore, the next largest groups, the ljaw constitute $10 \%$ occupy the Niger Delta region and number 18 million. The Kanuri constitute $4 \%$ of the Nigerian population, number 7.5 million and occupy the northeast part of the country. The Ibibio constitute $3.5 \%$ of Nigeria's population, number 6.5 million people and located east of the lbo. Lastly, the Tiv constitute $2.5 \%$ of Nigeria's population, numbering 4.5 million and are located in the Benue River region just north of the Ibo and Ibibio. Altogether these seven languages and people constitute $82 \%$ of Nigeria's total population. The remaining $18 \%$ of the population primarily occupies the Middle Belt (i.e., the region geographically and culturally separating the northern and southern parts of the country), south central and east constituting 33 million people speak one of Nigeria's other 500 mother tongues $[1,5]$. The Lelna is one of the latter ethnic groups and their language, C'Lela is one of these languages.

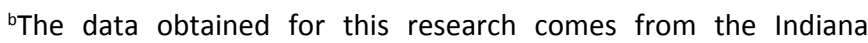
University South Bend Institutional Review Board approved preliminary research on traditional medicine among the Lelna in 2007 and 2011. While attempting to determine scientifically identify Lelna plants (by knowing their Hausa names. See Etkin [48]) used to prevent and treat malaria and pregnancy related health issues my research participants (traditional healers) enthusiastically gave me C'Lela names but could not provide me with Hausa names. The participants said they did not know the Hausa names. From this, I concluded that many Lelna do not necessarily possess an extensive knowledge of the Hausa language concerning ethnobotany, although they live in a predominantly Hausa area. More importantly, for many Lelna knowledge of Hausa appears situational (i.e. only used in limited and particular context such as greetings and market situations with non-Lelna), and most significantly, many Lelna continue to place a high value on their language and possess social and cultural mechanisms to maintain it.
Religiously, Nigeria is $49.3 \%$ Christian, $48.8 \%$ Muslim, and $1.4 \%$ African Traditional Religions [6]. The religious composition of Nigeria manifests itself regionally as well. Muslims predominate the north while Christianity (and to a lesser extent indigenous/traditional beliefs) predominate the south. Moreover, certain groups tend to adhere to a certain religion more than another religion. For example, the Hausa tend to be overwhelmingly Muslims, whereas the Ibo tend to be overwhelmingly Christian. The Yoruba tend to be Christian but have substantial number Muslim adherents as well. All three also possess a minority of people in their group that adhere to their traditional beliefs and practices [7]. Figures on the religious composition are scarce and often differ by source. One of the few documented and recent sources, the Joshua Project [8], a Christian missionary organization indicates that $50 \%$ of the Lelna follow their indigenous/traditional religion, 30\% are Muslim, and 20\% are Christians. Gunn and Conant [9] simply refer to the Lelna (referred to as Dakarkari in their text) as a non-Muslim people; whereas another source states that the Lelna are a majority Muslim group [10]. This author will take the differing estimates among sources as an indication that all three religious designations are well represented among the Lelna and today are a religiously diverse people.

\section{The Lelna of Northwestern Nigeria}

The Lelna are a population of approximately 136,000 inhabitants residing in the Zuru, Donko-Wasagu, and Sakaba Local Government Areas of Kebbi State (all formerly parts of Sokoto State) in northwestern Nigeria [11,12]. Until recently, the Lelna were referred to as the Dakarkari $[9,13,14]$. The origins of the name Dakarkari provide an insight into the historical interaction between Lelna and the Hausa. The name Dakarkari may be associated with the Hausa word daakaaree which means infantryman. The word daakaaree reflects the Lelna historical occupation as foot soldiers for the Hausa King of Kebbi since the eighteenth century. Others attribute the term to the Arabic word dakakir which means idolaters and suggests the non-Islamic or traditional religious practices of the Lelna. The Lelna are more likely to accept this first origin of Dakarkari than the second origin [11]. Augi [15] challenges these perspectives concerning the more popular origins of the ethnic designation, Dakarkari as "mere attempts at rationalization of some unknown or forgotten historical phenomenon" (96). Although the Lelna served the Hausa as soldiers, it must be noted that subsistence farming represented and continues to represent their primary occupation [16]. Today, a high number of Lelna also serve in Nigerian armed forces.

The current name of the Lelna refers to a number of related non-Islamic groups (Bangawa, Fakawa, Kelawa, and Lilawa) that served the Hausa. By the twentieth century, the Lilawa (Lelna) emerged to become the dominant group and language among these groups [11]. According to Augi [15], perspectives on the origins of the Lelna must not understate their diverse origins. The Lelna are more than likely the product of successive migrations of diverse people from outside of Zuruland (i.e. the Zuru Emirate) due to various social (i.e., pre-existing relationships with neighboring groups), political 
(i.e., increasing Hausa presence), and economic (i.e., seeking fertile agricultural land) factors into an area already populated by a people referred to as the Achipawa, the oldest confirmed inhabitants of the Zuruland. Augi [15] states that this interaction resulted in more cultural and linguistic influence of the Achipawa on these incoming migratory groups than vice versa.

Notwithstanding this influence of the Achipawa on these outside groups, Augi [15] adds that the migrants into Zuruland played a major role in shaping the area's history prior to the twentieth century in four major ways. Much of this remains central to Lelna culture to this day. First, the migrations lead to an increase in the local population and the establishment of several new settlements such as Dabai, Donko, Ribah, Senchi, and Zuru. Second, the migrations led to an increase of economic activity, namely in the agriculture, hunting, and the manufacturing and trade of iron and shea butter. Third, increased cultural and political interactions, most importantly the spread the $M^{\prime}$ gilø male initiation cult and intermarriage which would more than likely include the Golmo bridewealth/brideservice contract. The former two ways remain quite relevant to this day. Lastly, the increase in cultural and political communities in the region which in turn led to a shift in sociopolitical organization. Many of these groups were initially what would be characterized as segmented, but overtime would become more hierarchical and centralized. In addition to the Emir, the use and authority associated with the traditional title Gomo (for chiefs and other office holders) also remains in common use and practice.

\section{Linguistic Continuity and Change among the Lelna}

C'Lela (the Lelna language) belongs to the Western Kainji sub-group of the Benue-Congo branch of the $\mathrm{Ni}$ ger-Congo language family and contains the languages of some of the Lelna's neighbors such as the Dukwawa, utMa'in, and Gwamhi-Wuri [12]. In regards to thirteen level point Expanded Graded Intergenerational Disruption Scale (EGIDS) concerning language status ranging from 0 (International-The language is widely used between nations in trade, knowledge exchange, and international policy, e.g., English) and 10 (Extinct-The language is no longer used and no one retains a sense of ethnic identity associated with the language), C'Lela is classified as 6a (Vigorous-The language is used for face to face communication by all generations and the situation is sustainable). This would indicate that the C'Lela status as a language is secure but if one considers that level $6 \mathrm{~b}$ on the EGIDS scale is Threatened (i.e., the language is used for face to face communication within all generations, but is losing users), the language occupies a critical position concerning its survivability $[17,18]$.

Factors concerning the survivability of C'Lela concern its number of speakers and its speakers' location near the Hausa, the largest ethnolinguistic group in West Africa [1]. C'Lela's location in Northern Nigeria reflects an even larger linguistic circumstance in that it lies on the border between the two largest of the five major language families in Africa, the Niger-Congo (e.g., Yoruba) and Afro-Asiatic (e.g., Hausa) language families [16]. C'Lela also occupies the northernmost fringes of Nigeria's Middle Belt, those one of the most ethnically diverse regions of the country. Most of the ethnic groups in the region are dwarfed by the Nigeria's largest regional groups, the Hausa, Yoruba, Ibo, Kanuri, Tiv, and Nupe [19]. In response, these smaller groups must learn and utilize one or more of these larger regional languages for access to regional economic, political, and social resources. Furthermore, as with most formally colonized countries, the language of their colonizer serves as the language of law and education. In the Nigeria, that language is English. As a result, most Nigerians at a minimum are fluent in their native language, a regional language and the national language. Given the prestige and power associated with the regional and national languages, an emphasis is placed on learning and using the national and regional languages at the expense of the local language. Although typically referred to as linguistic hegemony, Brann [20] refers to this as discursive discrimination and marginalization. Perhaps this explains a comment expressed by a Lelna elder in 2012.

Twenty years ago, they said our language would be gone by now. We are still here.

Such a statement evokes the question. How does C'Lela remain a relatively thriving language in so close of a presence to the Hausa and the high value placed on English? There are some reasonable explanations for this.

The first explanation is of a demographic nature. According to Krauss [21], $90 \%$ of the 6,000 or so living languages are at risk of becoming extinct within this century because of language suppression factors such as linguistic hegemony, assimilatory education, and electronic media bombardment. Krauss also states that a language needs a minimum of 100,000 native speakers in order remain sustainable in the presence of these language suppression factors. At the time of the publication of Krauss' article, the Lelna had a population around 90,000, a number that would put C'Lela at risk of endangerment [11]. However, given the typical population growth of the region (conservatively around $2 \%$ ) since the early 1990s, the Lelna now have a population of 136,000 and thus demographically may have numerical insurance against language endangerment [12].

Mufwene [22] and Simons and Lewis [23] challenge Krauss' [21] assertion concerning the large number of languages at risk of extinction or endangerment. According to these authors the threat of language extinction or endangerment of a given language has been shaped by their native speakers' particular colonization experience. More specifically, persons with a colonial experience characterized primarily by either exploitation or trade which resulted in limited and less economically dependent native contact are more likely to have retained their language than those with a colonial experience characterized by settlement which resulted in prolonged and economically dependent contact. These particular colonization efforts express themselves geographically and have linguistic implications. Countries or regions with experiences of settle- 
ment colonization such as Australia, Canada, and the United States possess more dramatic language endangerment than those regions with experiences of trade and exploitative colonization such as Melanesia and Sub-Saharan Africa. I would add that this may appear a valid analysis concerning language the endangerment or extinction of indigenous languages in the presence of colonial languages but does not address what occurs in highly diverse countries or regions regarding the interaction between of smaller indigenous languages with larger indigenous languages. How does a highly ethnolinguistically diverse country with a few larger and regionally situated indigenous ethnolinguistic groups like Nigeria address this linguistic diversity? The response denotes the second explanation concerning the persistence of C'Lela. Nigeria has established bureaucratic structures that accommodate the vast linguistic diversity in the country.

At Nigeria's independence in 1960, the country was divided into three bureaucratic/administrative regions reflecting the countries major geographically situated ethnic groups referred to by [20] as the decamillionaires (since each as a population of at least ten million members), Northern Region (Hausa), Western Region (Yoruba), and Eastern Region (Ibo). Yet in 1967, in response to the Biafrian (Ibo separatist) conflict Nigeria altered its regional administrative structure approach in favor of a state administrative structure consisting of 12 states. In 1991, these states have been further divided into its current 36 state and Federal Capital Territory (Abuja) structure. According to Brann [20], these new state formations reflect preexisting ethnolinguistic boundaries of the country's largest groups including those groups with over a million people (referred to as the millionaires and whose languages are referred to as network languages). Moreover, the Nigerian government further divided the states into 774 local government authorities (LGAs) which coincide with those ethnolinguistically based groups with around 100,000 or more people. Yet, Brann [20] indicates that $60 \%$ of all of the LGAs are still dominated by one of Nigeria's three largest languages, an additional $18 \%$ of LGAs dominated by languages with at least 500,000 speakers, while only $20 \%$ are dominated by languages with around 100,000 or more speakers. One of these is the Zuru LGA (administered as an Emirate Council). The Zuru LGA in turn is subdivided into five administrative districts: Dabai, Donko, Fakai, Sakaba, and Wassagu. The LGAs administrative center, the emirate headquarters is Zuru town located in the Dabai district [16]. C'Lela is the dominant/designated language in the Zuru LGA. Although far from perfect, such an effort reflects Nigeria's efforts to promote a national identity while insuring local cultural identity $[24,25]$.

Bitiyong [16] indicates that the Zuru LGA is a multiethnic area comprised of people that fall into two broad categories. The first consists of people which claim either indigeneity or long-term residence in the area and possess traditional rights to the land. These include people such as the Achifawa, Bangawa, Dukawa, Fakawa, Kambari, Katsinawa, and the Lelna. The second consists of more recent settlers, many from $\mathrm{Ni}$ - geria's larger ethnic groups such as the Fulani, Hausa, Igbo, Yoruba, and as well as others from other parts of Nigeria. These peoples consider themselves as strangers and claim no traditional rights to the land, although some have histories and interactions with people in the area dating back hundreds of years. This interaction among the diversity of groups would not be possible without the ability of the people in the area to speak multiple languages.

Thirdly, the utilization of a diversity of languages in Nigeria varying by context demonstrates the high degree of multilingualism within the country in general and the Zuru LGA in particular. This multilingualism may in actuality maintain or at a minimum slow the pace of language endangerment since particular language usage is encouraged in certain contexts. In regards to the Lelna, this multilingualism expresses itself as follows: Speak C'Lela at the home and village level, speak Hausa in the market place and while interacting with state level bureaucracy (including access to civil services and employment), and speak English (formal English and/or Nigerian Pidgin English when in non-Hausa or Lelna settings [26].

Aito [24] states that language use and government communication in Nigeria is a three-tiered process referring to different languages at the federal, regional, and local levels, called demolects, choralects, and chthonolects respectively. According to Aito [24], this three-tiered expression is actually occurring to the detriment of chthonolects and violates the 1988 Cultural Policy of Nigeria which promotes the use local languages. In my opinion, such a three tiered practice at this time does not endanger C'Lela because of the low levels of English literacy, degree of economic independence since the Lelna are primarily subsistence farmers (i.e., they do not need Hausa or English to survive), and the strong sense of ethnolinguistic identity present in Zuru LGA.

If C'Lela is threatened in any manner it would be the teaching of Hausa in order to promote multilingualism, not English since there is limited access to extensive English education for most Lelna. Furthermore, the promotion of Hausa occurs more to the desires of Lelna youth to abandon their subsistence lifestyle and leave Zuru in favor of a life in one of the larger urban centers in the region such as Birnin Kebbi, Koko, or Kontagora. Even this would not necessarily result in a loss of C'Lela since those Lelna that migrate out of the region periodically return to Zuru to maintain family ties. The Lelna also counter this pressure to learn Hausa by promoting the use of C'Lela in the home and community contexts (i.e., cultural festivals). There are children's books, written in C'Lela by the Lelna authors to promote the language. One of my most unexpected experiences while in Zuru in 2011 involved a young Lelna woman proudly showing me some her books written in C'Lela she received while in school $[27,28]$. Such efforts, more specifically 1) A favoring of linguistic diversity by the dominant culture (in this sense the Nigerian government); 2) The development of a literature using the language in question (i.e., the children's books); 3) Involving the speakers of the language in the restoration efforts, the creation of easy to use language materials (i.e., the native authors of the 
children's books); and 4) Maintaining environments that promote the continued use of the language (i.e., the cultural festivals) coincide with some of Yamamoto's [29] recommended approaches to maintain or restore threatened languages.

Dettweiler [12] expresses that what is occurring in among the Lelna is more appropriately designated a stable diaglossia rather than multilingualism (or in his words widespread bilingualism, referring to knowledge and use of both C'Lela and Hausa). Multilingualism commonly refers to individuals who can speak multiple languages with one of those languages serving as the dominant or primary language of the speaker and often occurring in an assimilationist context. Diaglossia on the other hand refers to a community who uses two languages but in different situations. One of the languages tends to be used in a more formal (often written) context while the other is utilized in less formal or spoken context [30]. Nevertheless, this author believes the use of multilingualism is more appropriate because the high degree of ethnic and linguistic diversity in the region can result in different combinations language knowledge and use that go beyond the C'Lela-Hausa dichotomy.

With said, it must also be added that given the ethnic diversity in the region, the Lelna responded by promoting not only multilingualism but multiculturalism as well. Mirroring the three-tiered language system present in the area, cultural expression tends to be three tiered as well. In reference to this specific region, the Lelna conduct yearly Lelna centered cultural festivals, speak Hausa in the larger markets and when conversing with non-Lelna people, reside in an Islamic Emirate (Zuru) in a Nigeria State (Kebbi) regulated under Sharia Law, typically wear either Hausa or Western clothing, and purchase and consume manufactured products produced locally and from around the world [11,31]. What is occurring in Zuru and for that matter most of Africa typifies what the Mazrui [32] calls the Triple Heritage. Mazrui expresses that African culture is conglomeration of indigenous African, Islamic and Western elements. Mazuri's Triple Heritage is clearly apparent in regard to characterizing the contemporary expression of Lelna religious beliefs and practices.

\section{Religious Continuity and Change among the Lelna}

Bako [33] provides one of the most succinct yet comprehensive descriptions of traditional religious beliefs and practices in Zuruland. To begin, Bako stresses these that beliefs and practices passed down by the ancestors have been modified over the generations to address the situation at hand and needs of the people. As a result, traditional religion in Zuruland is characterized by a lack of rigidity to the extent that no definitive list of gods exist and that religious beliefs and practices may vary even though these may possess the same or similar names. With this said, Bako [33] and Mohammed [34] describe seven traditional religious phenomena common to Zuruland.

The first and one of the most important forms of religious expression is the reverence towards the ancestors. In
C'Lela, the ancestors are known as $\varnothing \mathrm{knu}$. These ancestors are considered intermediaries between the living and the dead who function to convey worshippers' prayers to the Supreme Being (considered remote see Mohammad [34]). These ancestors appear to be former living beings who have met certain standards. These include, living to an old age, having lived a morally sound life, and having descendants that survive their death to continue to ensure the continuance of their family. Ancestor reverence is quite common Africa and especially present in those societies with unilineal descent. This assertion coincides with Lelna, a patrilineal society. Bako [33] notes that several groups in Zululand including the Lelna believe the $\varnothing \mathrm{knu}$ can influence the lives of living descendants. In response, those believing this make sacrifices at certain shrines, especially when things are not going well. These $\varnothing$ knu only bring good things and are never the causes of misfortune.

Another significant traditional religious phenomenon in Zuruland, is the $M^{\prime}$ gilø secret society. The $M^{\prime}$ gilø cult appears to the one of the oldest, most powerful, and widespread cults in Zuruland. Bako [33] states that $M^{\prime}$ gilø originated outside of Zululand in the city of Kotorkoshi located approximately 155 miles northwest of Zuruland is found as far south as Kontagora 185 miles from Kotorkoshi and 75 miles from Zuru $(\text { see }[9,14])^{c}$. Like the previously discussed form of ancestor reverence, the primary component of the $M^{\prime}$ gilø secret society includes ancestor spirit (also an intermediary between human and the Supreme Being) reverence but it differs from former in that the $M^{\prime}$ gilø ancestor spirit can award or punish. Priests of the cult are charged with settling issues ranging from land use disputes to marital conflict to witchcraft accusations through their communication with $M^{\prime}$ gilø [33,35]. Mohammed [34] indicates that nearly all Lelna villages have a local priest selected by the council of elders who serves as the custodian of the local M'gilø (referred to as Magileu in Mohammed's thesis and Magiro in Abdullahi [35]) shrine. All of these priests are led by a chief priest called Gom-Vum-Magileu in C'Lela. Actual arbitration between two parties involves seeking out this local priest who can communicate directly to $M^{\prime}$ gilø who in turn informs the priest of the pronouncement. This includes providing an appropriate sacrifice requested by the priest of an animal typically a black goat, he-goat, ram, ewe, chicken (most common), or duck and local beer called burkutu as a libation to $M^{\prime}$ gilø. The priest will then lead the two parties through the forest to $M^{\prime}$ gil $\varnothing$, have the two parties state their claims by oath and ask M'gilø to provide a resolution to the concern, then they sacrifice their animals. M'gilø takes the blood while the priest takes the meat. A judgment concerning the issue is provided a few days later through the priest. Those members of the party that lie will become sickened and die from $M^{\prime}$ gilø if they do not confess guilt or beg for forgiveness. Those requesting forgiveness must return to the priest and sacrifice a black he-goat.

'The shortest distances by road determined by Google Maps [49]. Provided by Google Maps in kilometers and converted to miles. 
The M'gilø secret society also conducts the male initiation ceremony which involves instilling discipline and training young men to become competent farmers. The M'gilø festival occurs annually, involves dog sacrifice, and the consumption of a special wine made from guinea-corn called Mkya. Women are excluded from most if not all these activities for it is believed they would die at the site of $M^{\prime}$ gilø. These activities denote the social, political, economic, and educational roles the $M^{\prime}$ gilø secret society fulfills in Lelna society and explains why it remains present to this day.

In addition to the $M^{\prime}$ gilø spirit, Mohammed [34] indicates the significance of the Girmace spirit among the Lelna. The Girmace is regarded by its worshippers as a spirit who manifests itself in the form of a crocodile who resides in a river just near one of the older inhabited towns of the Lelna. As with the $M^{\prime}$ gilø spirit, the Girmace has a priest who has the ability to convey the requests of worshippers to the Girmace. These requests typically concern matters of fertility and fortune. Worshippers appease Girmace by showing respect through demonstrating humility and appropriate dress and offer a sacrifice of a ram, goat, chicken, or form of food. Once the sacrifice is made, the priest will lead the worshipper to the location of the Girmace, say a prayer which asks Girmace to grant the worshipper's request. If the worshipper is deemed worthy, Girmace will appear and accept the worshipper's sacrifice. If Girmace does not appear, the priest asks the worshipper to go home with their sacrifice and return at a later time. The beliefs and practices pertaining to Girmace differ from the $M^{\prime}$ gilø in that there is only one Girmace priest, Girmace is never harmful, and both men and women are free to consult Girmace.

The next two traditional phenomena pertain to the Dibiti and Uhola agricultural festivals. Both of these are seasonal. The Dibiti occurs when the crops are grown but not harvested. The purpose of this festival is to pray to the god of rain for the proper weather conditions to facilitate the proper growth of crops. After the crops are harvested, Lelna perform the Uhola festival. The Uhola festival thanks through offerings of guinea corn beer and millet (staples of the Lelna agricultural economy) to the god of rain for the providing proper rain to grow and sufficient energy to harvest the crops. It is conducted through its shrine called Købdin Menke in C'Lela [31,33]. Bako [33] indicates that Muslim Lelna see a similarity between Dibiti and Uhola festivals and the Islamic holidays of the Id-el-Kabir and Id-el-Fitr, respectively. The Id-el-Kabir marks the end of the year whereas the Id-el-Fitr marks the beginning of the year. Such observations denote the religiously syncretic if not possibly compatible nature of traditional Lelna religion and Islam.

The last two traditional religious phenomena common in Zuruland are the Wøh (or Makoli) funeral ceremony, and Golmo bridewealth/brideservice contract. The $W ø h$ funeral ceremony occurs one year after the death of the deceased. This is a special memorial service conducted by the deceased's family that emancipates the deceased's soul from the region of the dead. Prior to the $W \varnothing h$, the community is informed so everyone consanguineally and affinally connected to the deceased is obligated to contribute toward the expenses of the ceremony [33]. Marriage among those Lelna adhering to traditional religious beliefs and practices includes the Golmo contract. The Golmo contract requires young men to work on their future father in laws farms for five to seven years. Prospective suitors cannot marry or for that matter have any interaction with their prospective bride until this is completed. The number of years required for contract fulfillment and who can participate a particular contract is highly organized (i.e., arranged). As stated with the above religious phenomena, Lelna traditional religious beliefs and practices are well integrated into other aspects of their culture [16]. This integration of traditional Lelna religion with other aspects of Lelna culture may serve to either maintain certain components of traditional Lelna religion or result in a transformation of traditional Lelna religion when other integrated aspects of Lelna culture are significantly exposed to people with Western and Islamic cultural beliefs and practices such as Christianity and Islam. The remainder of the paper will explore this by examining the influence of Christianity and Islam on Lelna culture in general and their traditional Lelna religion in particular.

\section{Islam and Christianity among the Lelna}

The earliest presence of Islam in Zuruland occurred in the fifteenth century as a result of the Muslim merchants from the Hausa city state of Katsina moving south to seek agriculturally favorable lands in an area that already possessed economic ties with the Hausa city states of Katsina, Kano, and Zanfara to the north, Jega in the northwest, Yawuri in the southwest, and Nupeland in the southeast. These merchants would serve in the dual role of merchant cleric, engaging in both commerce and the teaching of Islam. Throughout most of this time (until the early nineteenth century) Islam in Zuru was primarily present among the Katsina migrants and the Zuru ruling class [33]. This phenomenon of Islam existing only primarily among the migrant Muslim merchant and the local elites while the local majority retains their traditional religious beliefs and practices conforms to the typical pattern of early Islamic conversion in Africa explained by Horton [36].

Horton explains this stating that the Islamic conversion of local elites would broaden their world view strengthen their political and economic position by giving them links to powerful entities outside of their locality. In time, Muslim scholars, farmers, and hunters would migrate to Zuruland. By the end of the nineteenth century, a number of substantial conversions to Islam had occurred in Zuruland [33]. The conversion to Islam among the Lelna masses was a gradual process and more than likely occurred because it could be perceived as relatively more egalitarian (e.g., open to all people regardless of sex and social position) than some of the traditional practices such as the $M^{\prime}$ gil $\varnothing$ secret society and of the relative compatibility between the two religions (e.g., both believe in spirits that interact with the living, the use of protective amulets, and the acceptance of polygyny) $[32,33,37,38]$. Today, The Zuru LGA is administered as an Emirate Council, reflecting the administrative structure of the predominantly Muslim Nigeri- 
an State of Kebbi which is also regulated under Sharia Law. According to Olson [10], Muslim Lelna tend to belong to the Sunni branch of Islam and follow the Maliki (moderate) school of law.

Christianity's presence in Zuruland is attributed to missionary efforts promoted by the colonial government originating back to the 1920s and 1930s. The U.S. based, United Missionary Society (UMS) was the first Christian missionary group to come to Zuruland. The UMS's primary conversion strategy involved providing a western education to selected locals who would in turn head evangelization efforts. Early converts experienced harassment from the rest of the population but this changed upon the return of Lelna servicemen in the post-World War Two who had developed an interest in Christianity [33].

The first substantial Catholic presence occurred in 1951 with the arrival of an Irish priest. By this time, the Catholics experienced less harassment than the UMS converts. Bako [33], attributes this to the increasing presence of Christians already in the area due to the earlier UMS efforts. Since the 1960s several Catholic churches have been constructed to accommodate its expanding membership. Additional Christian entities such as the Christ Apostolic Church, Evangelical Church of West Africa, and Apostolic Society are also present in contemporary Zuruland.

Bako [33] mirroring Horton [36] attributes religious conversion in the region to local responses to the shift from a traditional economy to colonial capitalism. The traditional economy involved local production, distribution and consumption grounded in local or internal (less ethnically diverse) social relations while the colonial capitalist economy was more oriented toward non-local and more ethnically diverse social relations. Although nearly half of the Lelna are Christians and Muslims, many of those possessing these more global oriented religions continue to retain traditional beliefs and practices. For example, a Christian and former Muslim provided a narrative demonstrating this religiously syncretic character of Lelna Christians and Muslims:

I have a friend who lives in Lagos that sought out a [Western] medical doctor to cure a severe rash she had on her body. She visited several doctors, but efforts were ineffective. My friend asked me for advice. I advised her to return to Zuru to seek out a local doctor [traditional priest]. She travelled to Zuru to do this. During the consultation, the local doctor [traditional priest] asked her if she had eaten any crocodile meat. She said yes. The local doctor [traditional priest] then provided the cure and her rash went away.

To further explain her narrative, a Christian research participant expressed that her friend's consumption of crocodile meat was a taboo in her people's traditional religion. More specifically her friend's behavior was an offense to the Girmace spirit. The Girmace manifests itself in the material world in crocodiles and its shine located on a tributary of the Azuru River [34]. The participant then added that the Girmace spirit and its shrine are not only one the most powerful shrines in Zuru land but in all of Africa, if not the world. Later in our discussion, she also added that although the local Lelna chief is a Muslim, he could not have attained his position if he could not demonstrate to his supporters that he is well versed in the lore and ritual associated with the Girmace.

Throughout these increased exposure to Islam and Christianity, the traditional Lelna religion has adjusted to address these needs to the extent that it is highly variable in its expression throughout the region. The religious beliefs and practices of Lelna are the product past and present efforts to address their spiritual, social, and material needs. This explains the persistence of traditional Lelna religious beliefs and practices among today's Lelna Christians and Muslims.

\section{Conclusion}

Issues concerning linguistic and religious continuity and change among the Lelna must be understood in the greater context of ethnic identity development in Africa. According to Ranger [39], during the pre-colonial era (nineteenth century), most Africans possessed and moved between multiple identities shifting from political allegiances, clan affiliations, religious affiliations, and professional guilds which could cross "ethnic" lines. Wright [40] supports Ranger's description of pre-colonial African ethnic identity adding that pre-colonial Africa was characterized by amorphous political borders, roving villages, intergroup marriages, and multilingualism. Social categories such a class, caste, and village affiliation appear more relevant regarding identity in pre-colonial Africa. Such a characterization of pre-colonial identity demonstrates that many pre-colonial Africans possessed a view on ethnicity counter to Western perceptions on ethnic identity. Reader (cited in Wright [40]) sums up this view, "[E]thnicity was not a characteristic that was deeply rooted in the African past; it was a concisely crafted ideological tradition that was introduced during the colonial period" [41]. This assertion of the historical lack of emphasis on African ethnic identity has implications concerning linguistic and religious continuity and change among the Lelna.

First, the Lelna appear to have been multilingual for centuries. The Lelna have been interacting with other groups such as the Hausa since the eighteenth century and their indigenous language, C'Lela continues to exist. The Lelna speak $C^{\prime}$ Lela at home in Zuru and teach it in their schools along with Hausa and English to a lesser extent. They speak Hausa in the marketplace to non-Lelna and in the areas outside of Zuru. They speak English while in non-Hausa areas. Admittedly there is language hierarchy which places English at the top because of its national and global appeal, followed by Hausa with its regional appeal, and finally Lelna with its village and familial as well as bureaucratic LGA appeal. This makes each language relevant in its particular context, thereby promoting linguistic continuity.

Second, in regard to religious beliefs and practices the Lelna were and are multicultural. The traditional Lelna religion was flexible and diverse. Today's expression of 
traditional Lelna religious beliefs can also be described as flexible and diverse in that is exists in either in its exclusive indigenous form or in a syncretic form combined with either Christianity or Islam. This latter form would denote change, yet traditional elements still remain in Lelna Christianity and Islam. With this said, the very concepts that the author uses to label Lelna religious beliefs and practices are problematic given the contemporary religion expression of the Lelna. Although I say Lelna Christianity and Lelna Islam, I could have just as easily if not more accurately said contemporary Lelna religious beliefs with either Christian or Islamic components.

Third, we have to keep in mind that ethnic identity is not static because culture is highly dynamic. People move to new areas with new or similar environments, interact with others with similar or different cultures, and make economic and political decisions resulting in cultural convergence and divergence when deemed necessary. As a result, a discussion of continuity and change cannot be made without a point a reference. Who should establish this point of reference? What criteria should we use to assess continuity and change? These questions remind me of the classic emic and etic debates in anthropology and leads to more questions than answers. At a minimum, the issue of cultural change and continuity must be understood from the context of those who consider themselves to belong to the group in question and the motivations of those who wish to study cultural continuity and change. Those that study cultural continuity and change must keep in mind that any proclamations made on this issue must be considered transitory because of any subjective or arbitrary emphasis on any given cultural criteria and point of reference. The transitory nature of such research and its associated potential implications become particularly problematic due to the Nigeria's efforts to maintain the national cohesiveness of one of the most ethnically and linguistically diverse places in the world.

In addition, the tremendous amount of population growth Africa is anticipated to experience over the next century- much of this growth fueled by Nigeria will shape, Lelna linguistic and religious dynamics. According to the Population Reference Bureau [42], Nigeria population is expected to double from its mid-2018 population of 195.9 million to 410.6 million in 2050. If the Lelna mirror this growth, they may number over 250,000. Even if we question the assertions of Mufwene [22] and Simons and Lewis [23], this is well above Krauss' 100,000 minimum required for protection against from language endangerment. If we consider the influence of population growth on global religious dynamics, Africa will also increase it numbers of Christians and Muslims in reference to other parts of the world. The Pew Research Center [6] estimates that in 2050, $38.1 \%$ of all Christians in the world will live in Sub-Saharan Africa. This would make Sub-Saharan Africa home to 1.1 billion Christians and the largest proportion of Christians in any other region of the world. Sub-Saharan Africa's Christian population will dwarf the Christian populations of Europe and North America combined (740 million) at this same time. Furthermore, nearly a quarter (24.3\%) of all Muslims in 2050 will live in Sub-Saharan Africa. This will make Sub-Saharan Africa second to the Asia-Pacific region which will contain over half $(52.8 \%)$ of all of the world's Muslims. In regard to Islam in Nigeria in 2050, Muslims will constitute $58.5 \%$ of the population, while Christianity will drop to $39.3 \%$ of the population, while those adhering to African Traditional Religions will slightly increase to $1.8 \%$ of the population of Nigeria. It is not known how this will affect the Lelna. It is only hoped that the country continues to take effect steps to ensure peace and cooperation between its religiously diverse populations.

Nevertheless, the increase in proportion of Christians and Muslims in Sub-Saharan Africa in comparison to other regions of the world may shape the expressions of both religions globally. This particular expression, given the syncretic nature of religious expression in Sub-Saharan Africa may result in the presence of more traditional African religious beliefs and practices in Christianity and Islam outside of Africa [43,44]. As a result, scholars may be conducting more research on the influence of African culture on Christianity and Islam in the next few years than vice versa.

\section{References}

1. Ethnologue (2018) Geographic distribution of living languages.

2. Sparks Carolyn (2017) Encyclopedia Britannica 2017: Book of the year. Encyclopedia Britannica, Chicago, USA.

3. Moyo Ambrose (2013) Religion in Africa. In: April Gordon, Donald Gordon, Understanding contemporary Africa. Lynne Renner, London.

4. Olupona Jacob (2006) African traditional religions. In: Thomas Riggs, Worldmark encyclopedia of religion. Thomson Gale, Farmington Hills, MI.

5. Central Intelligence Agency (2018) The World Factbook.

6. Pew Research Center (2015) The future of world religions: Population Growth Projections, 2010-2050. Pew Research Center, Washington DC.

7. Weekes Richard (1984) Muslim peoples: A world ethnographic survey. Greenwood Press, Westport CT.

8. Joshua Project (2018) Lela, Dakarkari in Nigeria.

9. Gunn Harold, FP Conant (1960) Peoples of the middle Niger region, Northern Nigeria. In: Daryll Forde, Ethnographic survey of Africa. International African Institute, London.

10. Olson James (1996) The peoples of Africa: An Ethnohistorical Dictionary. Greenwood Press, Westport CT.

11. Dettweiler Stephen, Sonia Dettweiler (2005) Sociolinguistic survey (level one) of Lela people. SIL International, Jos, Nigeria.

12. Dettweiler Stephen (2015) C'Lela grammar portrait. SIL International, Jos, Nigeria.

13. Fitzgerald RTD (1942) The Dakarkari peoples of Sokoto Province, Nigeria: notes on their material culture. Man 42: 25-36.

14. Harris PG (1938) Notes on the Dakarkari peoples of Sokoto Province, Nigeria. J R Anthropol Inst 68: 113-152.

15. Augi Abdullahi (1990) A survey of social and political history of Zuru Emirate Before 1900 A.D. In: Abdullahi Augi, Shehu Lawal, 
Citation: Randall T (2020) Linguistic and Religious Continuity and Change among the Lelna of Northwestern Nigeria. Insights Anthropol 4(1):224-232

Studies in History of the People of Zuru Emirate. Fourth Dimension Publishing, Enugu, Nigeria.

16. Bitiyong YI (1990) A survey in the Zuru Emirate Region, Sokoto State. In: Abdullahi Augi, Shehu Lawal, Studies in History of the People of Zuru Emirate. Fourth Dimension Publishing, Enugu, Nigeria.

17. Lewis M Paul, Gary F Simons, Charles D Fennig (2016) Ethnologue: Languages of the World, Nineteenth edition. SIL International, Dallas, Texas.

18. Mihas Elena, Bernard Perley, Gabriel Rei-Doval, et al. (2013) Responses to language endangerment- in honor of Mickey Noonan: New directions in language documentation and language revitalization. John Benjamins Publishing Company, Amsterdam.

19. Godwin Aondona loratim-Uba (2009) Language endangerment and violent ethnic conflict link in the Middle Belt Nigeria. Journal of Multilingual and Multicultural Development 30: 437-452.

20. Conrad Max Benedict Brann (1993) Democratisation of language use in public domains in Nigeria. Journal of Modern African Studies 31: 639-656.

21. Krauss Michael (1992) The world's languages in crisis. Language 68 4-10.

22. Mufwene Salikoko S (2002) Colonisation, globalisation, and the future of languages in the twenty-first century. International Journal on Multicultural Societies 4: 162-193.

23. Simons, Gary and Lewis, M. Paul (2013) The world's languages in crisis: A 20-year update. In: Mihas, Elena, Bernard Perley, Gabriel Rei-Doval, Kathleen Wheatley, Responses to language endangerment- In honor of mickey noonan. New Directions in Language Documentation and Language Revitalization. John Benjamins Publishing Company, Amsterdam.

24. Aito Emmanuel (2008) A glottopolitical appraisal of diversity in nation building in Nigeria. The International Journal of Diversity in Organizations, Communities and Nations 8: 281-291.

25. Omachonu Gideon (2015) Language documentation: A dependable linguistic practice for minimizing the effects of endangerment on languages in Nigeria. The Nigerian Linguists Festschrift Series 12: 1-15.

26. Zubair Yahaya A, Patricia Sarah Achi (2017) Language choice in multilingual environments: A study of zuru community of Kebbi State, Nigeria. Issues in Language and Literary Studies 1: 1-14.

27. K'Bancho, Sunday Ango (2005) Rihican gebesein ko we napa. C'Lela translation and literacy association. Zuru, Nigeria.

28. Rikoko, Bulus Doro, Matthew Earwicker, et al. (2001) A first dictionary of Lelna culture and wildlife. Lelna Language Development Secretariat, Zuru, Nigeria.

29. Yamamoto Akira (1998) Retrospect and prospect on new emerging language communities. In: Nicholas Ostler Bath, Endangered Languages: What Role for the Specialist? Foundation for Endangered Languages, United Kingdom.

30. Fishman Joshua (2007) Bilingualism with and without diaglossia; diaglossia with or without Bilingualism. In: Wei Li. The Bilingualism Reader, Second Edition. Routledge, New York.

31. Philip Mark Dudu (2008) The Zuru festival of arts and culture in pictures. Uhola Magazine. Na-Hweraka Resources Ltd, Zuru, Kebbi State, Nigeria.

32. Mazrui Ali (1986) The Africans: A triple heritage. Little, Brown and Company, Boston.

33. Bako Ahmed (1990) Transition and changes in religions and belief systems in Zuru Emirate. In: Abdullahi Augi, Shehu Lawal, Studies in History of the People of Zuru Emirate. Fourth Dimension Publishing, Enugu, Nigeria.

34. Mohammed Samaila (1982) Some aspects of the culture and Institutions of the Dakarkari people examined through the light of their contiguity with the hausa people. MA Thesis: Bayero University - Kano, Nigeria.

35. Abdullahi Yusuf (2015) The relevance of traditional belief system among the fakkawa of Zuru Emirate. International Journal of Humanities and Cultural Studies 2: 29-37.

36. Horton Robin (1975) On the rationality of conversion, Part II. Africa 45: 373-399.

37. Falola Toyin, Steven Salm (2000) Islam. In Africa, volume two. In: Toyin Falola Durham, African cultures and societies before 1885 . Carolina Academic Press, NC.

38. Hanson John (1995) Islam and African Societies. In: Phyllis Martin, Patrick O'Meara, Africa, Third Edition. Indiana University Press, Bloomington.

39. Ranger Terrance (1997) The invention of tradition in colonial Africa. In: Roy Grinker, Christopher Steiner, Perspectives on Africa: $A$ reader in culture, history, and representation, Blackwell Publishing, Oxford.

40. Wright Donald (1999) What do you mean there are no tribes in Africa? Thoughts on boundaries: And related matters in precolonial Africa. History in Africa 26: 409-426.

41. Reader John (1998) Africa: A biography of the continent. Vintage, New York.

42. Population Reference Bureau (2018) 2018 World Population Data Sheet.

43. Gemmeke Amber (2009) Marabout women in Dakar: Creating authority in islamic knowledge. Africa 79: 129-147.

44. Phillips John (1990) The African heritage of white America. In: Joseph Galloway, Africanisms in America Culture. Indiana University Press, Bloomington.

45. Mbiti John (1969) Introduction to African religion. Heinemann, London.

46. Idowu E Bolagi (1973) African traditional religion: A definition. SCM Press, London.

47. Kitause Rimansikwe, Hilary Achunike (2013) Religion in Nigeria from 1900-2013. Research on Humanities and Social Sciences 3: 45-56.

48. Etkin Nina (1997) Antimalarial plants used by hausa in Northern Nigeria. Tropical Doctor 27: 12-16.

49. (2018) Google Maps:"Zuru LGA".

Copyright: (C) 2020 Randall T. This is an open-access article distributed under the terms of the Creative Commons Attribution License, which permits unrestricted use, distribution, and reproduction in any medium, provided the original author and source are credited. 